\title{
USING PRODUCT DESIGN METHODOLOGY IN TEACHING ON PUBLIC HEALTH AND LIFE
}

\author{
Mille GRøM \\ Oslo Metropolitan University
}

\begin{abstract}
This master study is a pilot research project on mental health and communication. In 2020 the interdisciplinary project 'Public health and life skills' was introduced as part of Norway's new national curriculum for primary and lower secondary education. The interdisciplinary project lacks diversity in its teaching methods. This pilot research project examines how design methodology can contribute to the development of a teaching method. The goal is to teach students to express their inner life, that is, the human mind. Through a method inspired by grounded theory, the project explores the assumption that a visual language for the inner life can prevent mental health problems. Arts and crafts is proposed as a subject where this visual language can be learned, as the curriculum renewal emphasises the value of creative work. The purpose of the method is not to be therapeutic in a professional sense, but rather to have preventive and health-promoting effects by teaching students to speak out and recognise how they feel. This approach should be further investigated in practice amongst teachers and then among students in a classroom situation. The pilot research project indicates that design methodology can have essential value in the development of a teaching programme in public health and life skills.
\end{abstract}

Keywords: Public health, professional renewal, mental health, creativity

\section{INTRODUCTION: EDUCATIONAL TOOLS FOR PUBLIC HEALTH}

In the autumn of 2020, the new curriculum for primary and lower secondary education in Norway was introduced. The purpose is to give students future-oriented in-depth learning [1]. One of the overarching themes in the curriculum is public health and life skills and is intended to have a preventive effect and to promote good mental and physical health [2]. A study from 2019 shows that such competence is in demand among both students and teachers. Students especially demand knowledge about how to cope with stress and adversity in life, while teachers seek knowledge about how these skills should be taught [3]. No specific guidelines or tools for teaching public health and life skills currently exist, other than the subjects in which it should be included. Among other things, social studies should make students aware of their own identity and 'offer perspectives on what a good life can be' [4].

\section{BACKGROUNDS: POOR MENTAL HEALTH IS EXPENSIVE}

Preventive work in mental health is valuable, as mental disorders are the most expensive disease group in Norway. Common disorders such as depression and anxiety cost more than severe disorders such as bipolar disorder and schizophrenia. This is because they lead to the loss of working days and because treatment has a relatively small effect in the long term. Prevention rather than treatment is the best solution, both economically and socially [5]. Research shows that the effect of teaching about mental health in school is only short term. On the other hand, there is evidence that such teaching can reduce the likelihood of recurring severe illness. In addition, it can create a lower threshold for seeking help early [7]. Based on the pilot research project, the following research question was formulated: How can design methods contribute to developing a teaching method for the interdisciplinary project 'Public health and life skills' in primary and lower secondary education in Norway, with the goal of teaching children and young people to express their inner life? The issue was highlighted during the data collection. By inner life is meant the human mind and the unconscious and conscious. The project's goal was thus to come up with a preventive and health-promoting method that can be used for teaching the topic of public health and life skills in primary and lower secondary education. The solution had to focus on unity and community in a classroom situation. The aim of the pilot research project was to investigate what preventive work entails because the background information showed that this is very important in 
mental health. The method should therefore not have a therapeutic approach. The method was to be created by investigating whether creative expressions could stimulate conversations about the inner life. This is because the curriculum renewal emphasises the value of creative work [2].

\section{METHODS: A QUALITATIVE APPROACH}

The pilot project used a qualitative research method, inspired by grounded theory. This is a relevant method in this study because few or no design theories currently exist on preventive methods in mental health in Norwegian schools [8]. Data collection on topics related to public health and life skills will form the basis for a theory. An account will be given of curriculum renewal to provide a framework in which the development of the theory is established. A comparison of contradictory views on public health and life skills will then be presented, based on two booklets: Livsmestring på timeplanen. Rett medisin for elevene? [Life skills on the timetable: The right medicine for students?] written by philosopher and psychologist Ole Jacob Madsen and Folkehelse og livsmestring $i$ skolen [Public health and life skills in school] written by Karen Ringereide and Siri Landstad Thorkildsen, respectively special adviser and communications manager at the Regional Resource Centre on Violence, Traumatic Stress and Suicide Prevention Region South (RVTS South). This reveals the positive and negative aspects of public health and life skills, as well as the value of prevention. An in-depth interview with Terese Grøm, secretary general of LEVE (Norwegian Organisation for Suicide Survivors) will provide insight into what preventive work must entail. Selected examples will be given of teaching programmes on mental health and life skills that work, followed by an account of the value of pictorial communication. After an analysis, a possible approach is presented, including essential concepts.

\section{DATA COLLECTION}

\subsection{The curriculum renewal}

The purpose of learning in the curriculum renewal is, among other things: The pupils and apprentices must develop knowledge, skills and attitudes in order to be able to master their lives and to be able to participate in working life and society. The values in the objectives clause of the Education Act form the basis for the school's practice. Human dignity focuses on the value and equality of the individual. Identity and cultural diversity emphasise students' identity and belonging, as well as language. Critical thinking and ethical awareness should give students good judgment, and emphasise, among other things, artistic work as a good method. Creativity, engagement and inquisitiveness emphasise that the school should emphasise different ways of exploring and creating, including through 'sensing, and thinking, aesthetic forms of expression and practical activities. The value of artistic and cultural expression for the individual's personal development is also highlighted. Respect for nature and environmental awareness aim to make students climate conscious and environmentally conscious, while democracy and participation should teach them democracy in practice. The latter focuses on the value of being heard. An important principle in the curriculum renewal is social learning and development. This means the value of dialogue, and that students should be able to communicate their thoughts and feelings with each other. The new curriculum introduces three interdisciplinary themes based on current societal challenges: public health and life skills, democracy and citizenship, and sustainable development. The theme of public health and life skills is introduced to provide students with knowledge about physical and mental health. Life skills is defined as 'the ability to understand and to influence factors that are important for mastering one's own life'. The teaching should equip the students to cope with success and adversity and among other things, to handle thoughts, feelings and relationships [2]. Life skills are included in most subjects through topics such as sexuality, personal finance, drugs and literature [2]. No specific tools are proposed for how this should be implemented in practice. In the Norwegian subject curriculum, literature is proposed [9], and in the mathematics curriculum, personal economics is proposed [10]. No specific themes are proposed in the subject curricula for arts and crafts and music, but creative expression is highlighted as an important element [11].

\subsection{Contradictions}

There are few moderate voices in the debate on public health and life skills. Ole Jacob Madsen on the one hand, and Karen Ringereide and Siri Landstad Thorkildsen on the other. Ringereide and Landstad Thorkildsen believe that public health and life skills can create a more relevant school and prepare students for life after school. According to them, life skills align with the OECD's statement on the 
school of the future. They focus on the fact that happiness and joy can lead to life skills. At the same time, they promote the tradition of the Norwegian school as a preventive arena, with examples of traffic safety and dental health. They emphasise the principle that prevention measures should apply to everyone, not just to those in risk groups or with diagnoses [12]. Madsen, on the other hand, fears that life skills can create further social differences from which only the resourceful will benefit. Deprived students are described as students who experience serious problems with difficult family circumstances, substance abuse, bullying, abuse and the like. Madsen claims that these benefit more from treatment for mental health care issues [6]. He believes prevention is the wrong move, based on the research of Katherine Frohlich and Louise Potvin, researchers in preventive and social medicine at the University of Montreal. They point to general prevention as problematic because deprived people in society benefit less from such measures than those with more resources, and thus inequalities are created. Preventive work should rather be aimed at weaker groups in society [6]. Ringereide and Landstad Thorkildsen base their views on prevention on the work of Arne Holte, professor of health psychology [12]. Holte is inspired by the British epidemiologist Geoffrey Rose (1926-1993), who argued that general prevention is the right measure if the risk of disease is widespread [6]. Madsen believes that life skills can lead to students over diagnosing themselves because they know more about mental health. He refers to medical doctor Bruce Charlton, who warns that prevention can make a population sick [6]. Ringereide and Landstad Thorkildsen further argue for preventive measures with the American study Adverse Childhood Experiences, one of the largest studies on how a life can be affected by negative experiences in early childhood. The study points to risk factors that can have ripple effects in life despite a good innate potential. Ringereide and Landstad Thorkildsen believe that the school and the teacher can have a good preventive effect on these. They further criticise the educator Gert Biesta's view of what the school's tasks are, namely qualification, socialisation and subjectification. This involves knowledge to be able to participate in society, such as through work, the ability to function in society, and the ability to be oneself in interaction with others. To achieve this, students' most important needs must be met, according to the Australian psychologist Howard Bath, whose research deals with children exposed to trauma, but Ringereide and Landstad Thorkildsen believe it is transferable to the Norwegian school system. The needs are 'good relationships and help to regulate emotions, impulses and behaviour'. These are based on what are referred to as the three pillars: security, relationship and emotion regulation. Madsen is critical of such an individual focus and its ability to take responsibility for mastering his own life. 'Psychologization' of society is highlighted as the reason for the introduction of life skills. He refers to the transition of the Western world from collective societies to today's individual societies, with reference to the book The New Individualism: The Emotional Costs of Globalization, written by sociologists Anthony Elliott and Charles Lemert. Life has become an individual project, where individuals must create their own context. Furthermore, Madsen refers to the economist Robert Crawford, who in 1980 introduced the term 'healthism'. This was an image of a tendency to place health, illness and solutions in individual-based categories. Madsen also believes that self-regulation - the ability to control oneself - is unfortunate. Around 45 per cent of young girls consider school to be the biggest cause of stress and pressure. He therefore believes that the school is 'acquitted' by introducing life skills. At the same time, it is emphasised that young people are exposed to what is referred to as future discipline earlier than before. He suggests that the pressure must be reduced, and that the environment must be patient with young people trying to find their place in life [6].

\subsection{Examples of teaching programmes on mental health and life skills}

There are some examples of teaching programmes related to public health and life skills. RVTS South has created LINK - Livsmestring i norske klasserom [Life skills in Norwegian classrooms], a nationwide teaching programme in preventive mental health care. The programme involves students learning from each other through joint reflection and exchange of experiences on topics such as emotions, self-image and violence. The teacher is only supposed to facilitate discussions among the students [13]. As part of the so-called Trondheim project (2017-2018), selected secondary school students had mental health and life skills on the timetable throughout the school year, and were taught by a psychiatric nurse. The project showed that the students especially enjoyed learning about thoughts and feelings [14]. However, the occurrence of mental illness among students increased afterwards, possibly due to students' increased awareness of their own mental health. The reason may be greater attention to signs of this in oneself [15]. Klomsten and Uthus believe that public health and life skills must not deal with mental health [14]. Malin Kathrine Vik designed a resource booklet for the curriculum renewal in connection 
with her master's thesis in aesthetic subjects within drama and theatre communication in 2020. The booklet provides an introduction to how drama can be used to teach life skills. The booklet has been well received, and several teachers and professors in pedagogical studies have bought it [16].

\subsection{Images as a tool in communication}

During the Arts and Crafts Conference in 2013, Liv Klakegg Dahlin gave a lecture on arts and crafts and social media. Dahlin is head of studies and associate professor in the Department of Art, Design and Drama at the Faculty of Technology, Art and Design, Oslo Metropolitan University. In the lecture, Dahlin talks about the development of forms of communication. Before Johann Gutenberg's printing press, people read pictures as symbols and metaphors. They could not read plain text, unlike today where we can no longer read pictures. Going forward, it seems that images will again play an important role in our communication. This is due to our use of digital media, where images and symbols are central. Dahlin emphasises visuals as an important language, and the arts and crafts subject is based on much of this kind of knowledge. She argues that young people should create their own symbols to communicate. Visual means can explain complex things and enable us to understand the world we live in [17].

\subsection{Interview}

Terese Grøm is secretary general of LEVE (National Association for Survivors of Suicide). LEVE works on suicide prevention and has been involved in developing the Norwegian Government's zero vision for suicide in Norway, which was presented in the autumn of 2020. The organisation is pleased that mental health and life skills are highlighted and discussed. Grøm emphasises the importance of changing the causes of stress and problems among young people rather than just finding a tool. She believes that part of the reason for young people's poor mental health is that society has moved from being a collective society to an individualistic one. One solution may be to cultivate the collective aspect of society. Grøm refers to the book Nature and Madness by Paul Shepard, which deals with the value and importance of having a biocentric perspective rather than an anthropocentric perspective. That is, nature is at the centre rather than man. The book discusses indigenous peoples' ways of building themselves up as human beings in harmony with nature, i.e., with their surroundings. Grøm links this to Aristotle's perspective of how as a human being one should treat and live with the environment. At the same time, Grøm points out the difference between the collective thinking of indigenous peoples and the Western world. Indigenous peoples are also characterised by the transfer of knowledge from their elders, which can include knowledge of life skills. Teachers must have learned to live as human beings in order to teach students about it. However, many teachers have not grown up in today's society, and therefore good training in teacher education must be provided. At the same time, society imposes even more responsibility on teachers. Teaching life skills can be developed on the basis of factors from the collective society and from the individualistic society. It should be about being human, that is, acknowledging that life goes up and down, and at the same time mature with it. The term 'life skills' is perhaps misleading, because it is really about anchoring and belonging, according to Grøm. As part of a preventive measure, life skills can offer students a language for articulating their inner life. It is important for individuals and their surroundings to be able to recognise when they experience life as difficult.

\section{DISCUSSION A TEACHING METHOD FOR PUBLIC HEALTH}

All data were categorised into themes using open coding. This was to make it easier to describe the topic in question [8]. The themes were: prevention, the individual, the community, communication, and pressure and stress. Furthermore, axial coding was used to define interaction between the different themes and subthemes. This provided some indications on which issues and topics the pilot research project should focus on. Mental health prevention is important for public health [5] and can take place in schools [12]. Madsen, for his part, believes that prevention through universal measures does not have sufficient effect [6], as research also shows [5]. Ringereide and Landstad Thorkildsen, however, claim that a combination of a universal and individual-based measure makes sense. They are concerned that coping with life should prevent mental health problems later in life [12]. One issue that arises, however, is whether teaching about mental health will lead to over diagnosing among students [6]. Deprived students are referred to as those who experience problems with difficult family circumstances, substance abuse, bullying, abuse and the like [6]. At the same time, it should be noted here that resourceful students also may experience the above-mentioned challenges. It can therefore be said that all students can 
benefit from public health and life skills. The individualistic society is cited as the reason for introducing the theme [6], and the focus of the teaching should be a combination of community and the individual. This language can be a visual language, because it makes it easier to communicate complex themes. The arts and crafts subject can teach this [17], but the programme can also draw inspiration from other creative school subjects [16]. Life skills do not necessarily have to be about mental health, either [14]. According to Grøm, teachers must receive a good basic education in life skills and be able to act as facilitators of discussion rather than teachers of how to master life [12]. As is well known, teachers already have a great deal of responsibility. On the basis of the data collection, this pilot research project proposed how a teaching method for public health and life skills can be developed.

\section{CONCLUSIONS}

The data collection showed that the curriculum renewal's values highlight creative work, commitment and participation [2]. It is therefore reasonable that the focus on the development of a method should lie here. The method is that a visual language for the inner life can prevent mental health problems. This means that students from first grade in primary school learn how to express their feelings and thoughts through form. A visual language can explain abstract themes in a simpler way. The teaching takes place in arts and crafts [17]. The inner life can be experienced as abstract but concretised by means of form. Also, it can be easier to talk about oneself from a distance, and it can seem as if one is talking about form and not about oneself. As Grøm mentions in the interview, the fact that both the individual and the environment recognise how the individual feels is important in order to mature as human beings. The purpose of the method is to teach students to speak out and recognise how they feel. It is also about learning about and reading others and the value of community.

A preventive measure is one that reduces the likelihood of needing treatment later in life. Some examples of teaching methods have been tested, but the long-term effects have not materialised. They may indicate that public health and life skills must follow students throughout the school year. Creative subjects can be used, and a visual language can be the solution. This knowledge is relevant for practitioners, educators and students within product design and participatory design. Also, the pilot research project shows that this approach expands knowledge about what is valuable design competence in fields other than design, which may contribute to solving the societal issues we face today. This illustrates the relevance of design methodology in interdisciplinary research.

Using a ground theory approach, this study explored how a teaching method for the interdisciplinary topic of public health and life skills can be developed. It has implications for what the further process of development should entail. Furthermore, it is appropriate to examine the theory in practice. In the first instance, this should be done among teachers before being further explored in a classroom context.

\section{REFERENCES}

[1] Regjeringen. Fornyer skolens innhold: Nye lareplaner skal gi elevene tid til mer dybdelaring. Available: https://www.regjeringen.no/no/aktuelt/nye-lareplaner-skal-gi-elevene-tid-til-merfordypning/id2678138/?expand=factbox2678140. [Accessed on 2020, 12 October], (2019) 18 November.

[2] Utdanningsdirektoratet. Overordnet del-verdier og prinsipper for grunnopplaringen. pp. 3-9, 11-12. Available: https://www.udir.no/lk20/overordnet-del/prinsipper-for-laring- utvikling-ogdanning/tverrfaglige-temaer/folkehelse-og-livsmestring/. [Accessed on 2020, 12 October].

[3] Klomsten A. T. and Stenseng F. Behovet for å lære om egne følelser. Utdanningsforskning. In: Bedre Skole 1/2019. Available: https://utdanningsforskning.no/artikler/behovet-for-a-lare-omegne-folelser/. [Accessed on 2020, 15 September].

[4] Utdanningsdirektoratet. Lareplan $i$ samfunnsfag. p. 4. Available: https://www.udir.no/laring-ogtrivsel/lareplanverket/nye-lareplaner-i-grunnskolen-og-gjennomgaende-fag-vgo. [Accessed on 2020, 12 October].

[5] Holte A. Slik fremmer vi psykisk helse, forebygger psykiske lidelser og får en mer fornuftig samfunnsøkonomi. Utposten. Fagblad for Allmenn- og Samfunnsmedisin. 2, 2017. Available: https://www.utposten.no/i/2017/2/utposten-2-2017b-457. [Accessed on 2020, 14 October].

[6] Madsen O. J. Livsmestring på timeplanen. Rett medisin for elevene? 2020. (Spartacus Forlag AS), pp. 35-40, 44, 72-73, 76-79, 97, 104-105, 117-119.

[7] Andersen B. J. Effekten av undervisning om psykisk helse i videregående skoler. [Doctoral dissertation]. Oslo University. p. 6. 
[8] Muratovski G. Research for Designers: A Guide to Methods and Practice. 2016. (Sage Publications Ltd) pp. 98-99.

[9] Utdanningsdirektoratet. Laereplan i norsk. p. 3. Available: https://data.udir.no/k106/v201906/laereplaner-lk20/NOR01-06.pdf?lang=nob. [Accessed on 2020, 12 October].

[10] Utdanningsdirektoratet. Lareplan i matematikk. p. 4. Available: https://data.udir.no/k106/v201906/laereplaner-lk20/MAT01-05.pdf?lang=nno. [Accessed on 2020, 12 October].

[11] Utdanningsdirektoratet. Laereplan i kunst og håndverk. p. 3. Available: https://data.udir.no/k106/v201906/laereplaner-lk20/KHV01-02.pdf?lang=nob. [Accessed on 2020, 12 October].

[12] Ringereide K. and Landstad T. Folkehelse og livsmestring $i$ skolen. 2019. (Pedlex), pp. 12, 15$16,18,21-22,34,37,39-40$.

[13] Laererveiledning til LINK. p. 9. Available: https://www.linktillivet.no/filer/LINK_Laererveiledning_2020.pdf. [Accessed on 2020, 15 October].

[14] Klomsten A. T. and Uthus M. En sakte forvandling. En kvalitativ studie av elevers erfaringer med å lære om psykisk helse i skolen. Nordisk Tidsskrift for Utdanning og Praksis, 2020. 14[2], 122-139. https://doi.org/10.23865/up.v14.2210.

[15] Halvorsen P. Psykiske helseplager fortsatte å øke. Tidsskrift for Norsk psykologforening. 2020. Available: https://psykologtidsskriftet.no/aktuelt/2020/08/psykiske-helseplager-fortsatte-oke. [Accessed on 2020, 9 October].

[16] Vik M. K. Ressursheftet "Drama som laeringsform i grunnskolen". [Master's thesis]. Oslo Metropolital University. Available: https://padlet.com/kathrine_malin/ressurshefte [Accessed on 2020, 15 October].

[17] Klakegg Dahlin L. Kunst og håndverk og sosiale medier. Lecture given at DOGA kunst- og håndverkskonferansen. Oslo, 2013. Available: https://film.oslomet.no/10820436/11069877/0e62fe90ccaf636a0a7313a992f215d2/video_1080p/1 iv-klakegg-dahlin-kunst-og-0-video.mp4. [Accessed on 2020, 19 October] 